\title{
Kirkham, Pat, ed. 2013. Eva Zeisel: Life, Design, and Beauty. San Francisco: Chronicle Books. 255 pp. Illus.
}

\section{Reviewed by Judith Szapor, McGill University}

The Hungarian-born American designer Eva Zeisel (1906-2011) was one of the last of the great generation of Central European exiles who had escaped Hitler's Europe and gone on to enrich American science, art and intellectual life in innumerable ways. The significance of Eva Zeisel as a designer is eloquently summarized in the opening paragraph of Pat Kirkham's excellent biographical essay, introducing this volume:

A hugely talented designer with a tremendous life force, Eva Zeisel... was a major figure in the world of twentieth-century design, and both her work and her approach to it inspired, and continue to inspire, younger generations of designers. Eva worked in Hungary, Germany, and the Soviet Union in the 1920s and 1930s and was the preeminent designer of mass-produced ceramics for domestic use in the United States in the 1940s, 1950s, and early 1960s. During her extensive career she also worked for companies in Mexico, Italy, Hungary, England, Russia, India, and Japan. She was honored with many prestigious awards, from honorary degrees to two of the highest awards open to civilians in her native Hungary. (10).

From the black-glazed pottery of her native Hungary in the 1920s to the hand-blown glass lamps produced in Italy in 2012, the year after her death at the age of one hundred and five, Zeisel sustained an almost supernaturally long and successful artistic career. She never abandoned, as she liked to put it, her "playful search for beauty" (11). Having worked in geographical and temporal proximity to the Bauhaus, Zeisel's work has been frequently viewed as part of the Modernist movement, but she was always adamant to define her art in opposition to a restrictive, soulless interpretation of Modernism. She remained a true "modernist with a small m" (11) in her preoccupation with objects of everyday life; yet beauty, rather than a formal understanding of functionality, was her guide. To the end she kept launching new lines of furniture, glassware and giftware, along with reproductions of her timeless, classic lines of dinnerware; and they all bore the unmistakable curves and playful touches that made Zeisel's designs instantly recognizable.

From its cover that plays on the sensual shapes of Zeisel's designs, to the generous illustrations and thoughtful typography throughout, this volume is the ultimate coffee table book; and in a day and age when the printed book is considered a dying breed it reminds us why we love books. The volume provides the most comprehensive overview of the designer's life and work to date, thus surpassing such earlier, excellent but less ambitious attempts to present Zeisel and her work as Lucie Young's Eva Zeisel (eds. Marisa Bartolucci and Raul Cabra; San Francisco: Chronicle Books, 2003). Like the volume under review, the Compact Design Portfolio series in which Young's book appeared is also published by San Francisco's Chronicle Books Press and has Zeisel in good company among such design icons as Arne Jacobsen, Ingo Maurer, George Nelson and Karim Rashid, the Canadian designer whose curvy objects are reminiscent of Zeisel's work.

$($ (c) $)$ EY

ULIS D-Sente 
Szapor, Judith. "Kirkham, Pat, ed. 2013. Eva Zeisel: Life, Design, and Beauty.” Hungarian Cultural Studies. e-Journal of the American Hungarian Educators Association, Volume 7 (2014): http://ahea.pitt.edu DOI: $10.5195 /$ ahea.2014.159

Pat Kirkham, professor at the Bard Graduate Center, edited this collaborative volume and wrote the highly informative, comprehensive biographical essay, which is a richly contextualized account of Zeisel's trailblazing career and highly eventful life. A host of art historians and collectors of Zeisel's work contributed the twenty-four illustrated entries of Part Two of the book that describes Zeisel's main design lines and commissions from the 1920s to the 2010s. Complementing that part are three more brief chapters that survey Zeisel's work in furniture and glass as well as some of her unrealized projects. Part Three offers a generously illustrated taxonomy of shapes, bottom stamps and patterns that are no doubt highly useful to collectors, some of whom are the very contributors to this volume. Lastly, a useful chronology of Zeisel's life and work as well as meticulous endnotes complete the volume.

While most of its readers will most likely come from the ranks of design aficionados and those of the many fans and collectors of Zeisel's work, the volume will also appeal to anyone with an interest in the history of intellectual migration from Hitler's Europe and in the lives of the Hungarians among the émigrés. The best-known members of the latter cohort, from Leó Szilárd and Edward Teller, through Arthur Koestler and Robert Capa, to Michael Curtiz and Alexander Korda, have inspired a veritable cottage industry of biographies and prosopographies; recent examples range from the popular (e.g., Kati Marton's slightly sensationalist The Great Escape; New York: Simon \& Shuster, 2006), to the popular-scientific (e.g., István Hargittai, The Martians of Science: Five Physicists Who Changed the Twentieth Century; Oxford: Oxford University Press, 2006), and the scholarly (e.g., Tibor Frank, Double Exile: Migrations of Jewish-Hungarian Professionals Through Germany to the United States, 1919-1945; Bern: Peter Lang, 2009).

The Polanyi family members and especially two of Zeisel's uncles: the economist Karl Polanyi and the physico-chemist turned-philosopher Michael Polanyi, figure prominently in all these and other accounts of the great intellectual émigré wave. The Polanyi brothers' itineraries, from their emigration to Austria and Germany, respectively, and eventually to Great Britain and the U.S., illustrate the paths shared by many Hungarian émigrés. The success of the Polanyis in emigration has become legendary, prompting Laura Fermi, chronicler of The Illustrious Immigrants - The Intellectual Migration from Europe, 1930-1941 (Chicago: Chicago University Press, 1968), to use them as illustration to "the mystery of the Hungarian talent" (111).

Even the most rudimentary outline of the Polanyi family's history and accomplishments would fill more pages than what I have at my disposal for this review. Suffice it to say that with their geographical and social trajectory, the earlier generations of the Polanyi family demonstrate the positive drive of Jewish assimilation and embody the promise of a progressive, democratic Central Europe. In pre-World War I Hungary, members of this extended family were committed to political progress and artistic modernism, from the Social Democratic and Bourgeois Radical Parties, through liberal feminism and psychoanalysis, to the Galileo Circle, the group of the Eights, and the Sunday Circle. After the failed Hungarian revolutions in 1918 and 1919 most members of the Polanyi extended family emigrated to Austria, Germany, and Italy, and later to Great Britain, the U.S., and even Brazil, thus illustrating the pattern of multiple exile that is so characteristic of Hungarian émigrés.

Eva Zeisel was no exception to her family history of many immigrations but her work and her curiosity "to look behind the mountain" (26) took her further than most of her fellow émigrés: from Weimar Germany to the Soviet Union, and, in 1936-7, to sixteen months of imprisonment as a victim of Stalin's Great Purge. Shortly after her release from prison she had to flee Vienna on the eve of the Anschluss; and she finally reached New York, via Great Britain, in 
Szapor, Judith. "Kirkham, Pat, ed. 2013. Eva Zeisel: Life, Design, and Beauty." Hungarian Cultural Studies. e-Journal of the American Hungarian Educators Association, Volume 7 (2014): http://ahea.pitt.edu DOI: 10.5195/ahea.2014.159

the fall of 1938. Through her first marriage to Alexander Weissberg, a Polish-born physicist, and her second marriage to Hans Zeisel, the Czech-born and Vienna-educated legal scholar and sociologist, Eva demonstrated the Polanyi family's close ties to the European intellectual elite and, eventually, its refugee networks. Many of her family members and close friends, including the group of legendary Hungarian physicists, "the Martians," soon joined the best British and American universities. The fact that Eva's social circle included physicists and social scientists, along with artists and writers, is also a testament to an age we can only envy in our own era of increasing professional and intellectual compartmentalization. The Polanyis might have been exceptional in their excellence in so many fields but they were also representative of the Central European intellectual elite that erected no boundaries between science, social studies, music, arts and -- always -- politics.

I first met Eva Zeisel in 1994 while researching a scholarly history of the Polanyi family, focusing on Eva's mother, Laura Polanyi Stricker (Judith Szapor, The Hungarian Pocahontas: The Life and Times of Laura Polanyi Stricker, 1885-1959; New York: East European Studies, distributed by Columbia University Press, 2005). Over several visits, Eva proved to be most generous in sharing her memories and family documents. Her support of my project was crucial and, I believe, motivated by the close bond that connected her to her mother, Laura, who was a leading feminist and the first woman to earn a Ph.D. in history in pre-World War I Hungary. Laura Polanyi had visited Eva for extended periods in the Soviet Union and fought for her release from prison. In return, Eva had mobilized the family's networks to rescue Laura from the Gestapo's prison in Vienna on the eve of their emigration; in Eva's words they owed their lives to one another. Eva's prison memoir, along with essays and documents providing the context to her traumatic Soviet experiences, was made public shortly after her death as an e-book, edited by Zeisel's daughter and son-in-law (Jean Richards and Brent C. Brolin, eds. Eva Zeisel: A Soviet Prison Memoir; New York: Designers and Books, iBook, 2012). In her late eighties, when I met Eva Zeisel, her intellectual and physical energy seemed inexhaustible, perhaps fuelled by her undiminished curiosity about the world. Her wit and timing were perfectly intact at age ninetyfour, evidenced by the audience's reaction to her TED talk, recorded in 2001.

(https://www.ted.com/talks/eva_zeisel_on_the_playful_search_for_beauty)

Zeisel's shapely, curvy pieces of her dinnerware or glassware will be enjoyed in countless households for generations to come, confirming the success of her life-long mission to reconcile function and beauty. Throughout a life that exemplified the increasingly transnational and global nature of our world, Zeisel also remained true to her roots. In her later life, she made a habit of returning to the scenes of her early life and work: in 1958 to Germany to work on a commission for Rosenthal, in 1983 to Hungary to collaborate on a line of ceramics with the Zsolnay factory; and lastly, in 2000 to Russia, to reclaim her body of work in the Soviet Union.

Although her most important contribution was as an artist, Eva Zeisel also inherited her mother's role as keeper of the family's history. Unlike her mother Laura Polanyi, Zeisel was not trained as a historian and her frequently repeated credo: "to live in the present" (40) was regarded by many as her secret of surviving, with her personality and creativity intact, the trials of the twentieth century that she experienced in the flesh. Yet more than a mere survivor, she was also a historical actor who witnessed and shaped the events of the twentieth century. During a long pause between commissions, in the 1970s and 1980s Zeisel herself engaged in historical research as she wrote a study on an eighteenth-century episode of African-American history, as well as committed to paper her Soviet prison memoir. It was her mother who collected and kept the family's written records through multiple emigrations until her death in the U.S. in 1959; but 
Szapor, Judith. "Kirkham, Pat, ed. 2013. Eva Zeisel: Life, Design, and Beauty." Hungarian Cultural Studies. e-Journal of the American Hungarian Educators Association, Volume 7 (2014): http://ahea.pitt.edu DOI: $10.5195 /$ ahea.2014.159

it was Eva who returned them to Hungary when in the early 1980s, with the assistance of Erzsébet Vezér, she deposited the voluminous Polanyi Collection at the Hungarian National Széchényi Library.

This volume further confirms Eva Zeisel's already established stature as one of the leading designers of the twentieth century; therefore, it comes as no surprise that she figures prominently in a recent exhibition at New York's Museum of Modern Art, "Designing Women, 1890-1990." If the exhibition aims to show the profound ways in which the creativity of women shaped modern design, then Pat Kirkham's sensitivity to history and gender in her biographical essay in this volume highlights the challenges of making it as a female designer in the twentieth century. 